\title{
The determination of magnesium with titan yellow; masking interferences with phosphates
}

\section{J. CH. VAN SCHOUWENBURG}

Laboratory of Soils and Fertilizers, State Agricultural University, Wageningen, and Institute for Soil Fertility, Groningen, Netherlands

\section{Summary}

Used with Bradfield's method of determining $\mathrm{Mg}$, phosphate was found to be very effective as an agent masking heavy-metal interferences.

\section{Introduction}

The use of ethylene glycol bis-( $\beta$-aminoethylether)-N,N, $\mathbf{N}^{\prime}, \mathbf{N}^{\prime}$-tetraacetic acid (EGTA) as a masking agent for the interference of $\mathrm{Ca}$ in the determination of $\mathrm{Mg}$ with titan yellow has been proposed by BRADFIELD $(1961,1962)$. This procedure also prevents the formation of phosphate precipitates at high phosphate levels, thus making it possible to make use of the phosphate-complexing properties in preventing interference by the heavy metals.

The necessary introduction of a fairly high phosphate level called for some modifications in Bradfield's procedure. The concentrations of EGTA and triaethanolamine had to be raised, and $\mathrm{Mn}$ had to be introduced into the complexing solution.

To minimize the number of additions, the polyviol-titan yellow reagent solution and the compensating solution were mixed in advance. This mixture had to be renewed every other day.

The standard curve is S-shaped because the solubility product of $\mathrm{Mg}(\mathrm{OH})_{2}$ is not reached with the low $\mathrm{Mg}$ concentrations. To overcome this difficulty of the curve, some $\mathrm{Mg}$ has to be included in the compensating solution, taking into account the $\mathrm{Mg}$ contamination in the alkali.

\section{Reagents}

a. Compensating solution: dissolve $10 \mathrm{~g}$ of ethylene glycol bis- $(\beta$-aminoethylether $)-$ $\mathbf{N}, \mathbf{N}, \mathbf{N}^{\prime}, \mathbf{N}^{\prime}$-tetraacetic acid (EGTA manufactured by Fluka AG; Bucks SG; Switzerland) in the minimum volume of $\mathrm{KOH} 6 \mathrm{~N}$ (about $11 \mathrm{ml}$ ) and neutralize to pH 7 (indicator paper) with $\mathrm{HCl} 1 \mathrm{~N}$. Then add $20 \mathrm{ml}$ of triethanolamine, $0.0813 \mathrm{~g}$ of $\mathrm{MnSO}_{4} .4 \mathrm{aq}$ and $0.0894 \mathrm{~g}$ of $\mathrm{AlCl}_{3} .6$ aq (both dissolved in advance in a small quantity of distilled water) and $10 \mathrm{ml}$ of $\mathrm{Mg}$-standard solution (100 ppm). Make up with distilled water to a total volume of $400 \mathrm{ml}$. This compensating solution may be stored for at least a month.

Received for publication 18th June, 1964. 
b. Mg-standard solution (100 ppm): dissolve $1.013 \mathrm{~g}$ of $\mathrm{MgSO}_{4} .7$ aq in distilled water and make up to one litre.

c. Titan yellow reagent: add to $10 \mathrm{ml}$ of $0.1 \%$ aqueous titan yellow (Merck) $5 \mathrm{ml}$ of $1 \%$ polyvinyl alcohol (BDH) in distilled water, then $25 \mathrm{ml}$ of $1.75 \% \mathrm{KH}_{2} \mathrm{PO}_{4}$ in distilled water and $50 \mathrm{ml}$ of glycerine, and make up to a $100 \mathrm{ml}$ volume with distilled water. Use a fresh $0.1 \%$ titan-yellow solution every day.

d. Reagent mixture: mix titan-yellow reagent (no. 3) with an equal volume of compensating solution (No. 1).

e. $K O H 6 \mathrm{~N}$ : dissolve $336.6 \mathrm{~g}$ of $\mathrm{NaOH}$ and make up to one litre with distilled water.

f. NaOH $4 \mathrm{~N}$ : dissolve $160 \mathrm{~g}$ of $\mathrm{NaOH}$ and make up to one litre with distilled water.

g. $\mathrm{NaOH} 3.5 \mathrm{~N}$ : dissolve $140 \mathrm{~g}$ of $\mathrm{NaOH}$ and make up to one litre with distilled water.

In the Laboratory of Soils and Fertilizers, $\mathbf{M g}$ determinations are usually carried out either on Morgan soil extracts (LUNT et al., 1950; SCHUFFELEN et al., 1961) or on plant material after wet digestion according to LINDNER and HARLEY (1942) and LiNDNER (1944) or SCHAuMLöfFEL (1960). In order to adjust the determination of $\mathrm{Mg}$ to these three different conditions it was found necessary to use different alkali additions for each. Thus the same, fairly complex, reagent mixture could be used for all three conditions, only the concentrations and the kind of alkali being changed in order to introduce the amount of $\mathrm{Mg}$ required to reach the solubility product of $\mathrm{Mg}(\mathrm{OH})_{2}$.

When very acid digests (e.g. the Lindner-Harley digest) have to be neutralized, $\mathrm{NaOH}$, being less contaminated with $\mathrm{Mg}$, is preferred to $\mathrm{KOH}$, thus preventing the introduction of an excessive amount of $\mathrm{Mg}$.

\section{Procedure for a Morgan soil extract}

Extraction: $20 \mathrm{~g}$ of air-dry soil are mechanically shaken for 30 minutes with $50 \mathrm{ml}$ of the extracting solution $(100 \mathrm{~g}$ of sodium acetate $+30 \mathrm{ml}$ of glacial acetic acid, diluted to 1 litre with distilled water). An extract can be decolourized, if necessary, with $0.1 \mathrm{~g}$ of Medicinal Norit for each $10 \mathrm{ml}$ of the extract. Extracts of sandy soils are diluted with Morgan's solution in the ratio of $1: 5$ and extracts of clay soils in the ratio of $1: 20$.

Pipette $2 \mathrm{ml}$ of the diluted extract into test tubes and add $2 \mathrm{ml}$ of the reagent mix-

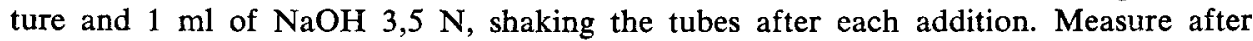
one hour (keep the test tubes in the dark (VAN WESEMAEL, 1961) at 550 n.m. and compare the results with a standard series containing 0-2-4-6-8-10-12-16 and $20 \gamma$ of $\mathrm{Mg}$ in $2 \mathrm{ml}$ of standard solution.

\section{Procedure for a Lindner-Harley digest of plant material (SCHUFFELEN et al., 1961)}

Digestion: weigh out $0.6 \mathrm{~g}$ of air-dry plant material in a $100 \mathrm{ml}$ volumetric flask. Add $5 \mathrm{ml}$ of sulphuric acid (s.g. 1.84) and (if possible) keep overnight to prevent excessive foaming. Use $4 \mathrm{ml}$ of sulphuric acid for the blank.

Heat on a hot plate and swirl gently to prevent foaming. Should foam enter the neck 
of the flask, add 1 or 2 drops of hydrogen peroxide (A.R. standard). After 10-minute intervals add 5 to 10 drops of hydrogen peroxide. Repeat this procedure until the resulting solution remains clear after 10 minutes at full heat (ca. $280^{\circ} \mathrm{C}$ ). Fill up to the mark with distilled water.

This solution has to be diluted $1: 1$ with distilled water to prevent crystallisation of $\mathrm{K}_{2} \mathrm{SO}_{4}$ after the final addition of $\mathrm{KOH}$ for the $\mathrm{Mg}$-determination.

Pipette $2 \mathrm{ml}$ of the $1: 1$ diluted extract into test tubes and add $2 \mathrm{ml}$ of the reagent mixture and $1 \mathrm{ml}$ of $\mathrm{KOH} 6 \mathrm{~N}$, shaking the tubes after each addition. Measure after one hour (keep the test tubes in the dark (VAN Wesemael, 1961)), at $550 \mathrm{n} . \mathrm{m}$. and compare the results with a standard series in diluted sulphuric acid $(20 \mathrm{ml}$ concentrated sulphuric acid per litre).

\section{Procedure for a Schaumlöffel digest of plant material (SchaumLöfFel, 1960)}

Digestion: weigh out $1 \mathrm{~g}$ of air-dry plant material in a $50 \mathrm{ml}$ graduated flask. Next add $10 \mathrm{ml}$ of an acid mixture $\left(\mathrm{HNO}_{3}: \mathrm{HClO}_{4}: \mathrm{H}_{2} \mathrm{SO}_{4}=10: 1: 0.25\right.$ ) and (if possible) keep overnight to prevent excessive foaming. Heat moderately on a hot plate. It should take 40 minutes or more for the $\mathrm{HNO}_{3}$ to distil off. Afterwards the heat is raised to full. Destruction is complete when only the sulphuric acid is left. Fill up to the mark with distilled water.

Pipette $2 \mathrm{ml}$ of the digests into test tubes and add $2 \mathrm{ml}$ of the reagent mixture and $1 \mathrm{ml}$ of $\mathrm{NaOH} 4 \mathrm{~N}$, shaking after each addtion. Measure after one hour (keep the test tubes in the dark (WESEMAEL, 1961)) at 550 n.m. and compare the results with a standard series in diluted sulphuric acid $(9 \mathrm{ml}$ concentrated sulphuric acid per litre).

\section{Interferences}

No interferences were detected with $5000 \gamma \mathrm{Ca} ; 300 \gamma \mathrm{Ni} ; 300 \gamma \mathrm{Co} ; 300 \gamma \mathrm{Cu}$; $200 \gamma \mathrm{Al} ; 300 \gamma \mathrm{Mn} ; 300 \gamma \mathrm{Fe}^{3} ; 150 \gamma \mathrm{Zn}$.

The $\mathrm{Mg}$ concentration was determined in a Morgan extract of a number of soils, using the described titan-yellow method and the atomic absorption method employed in this laboratory (TABLE).

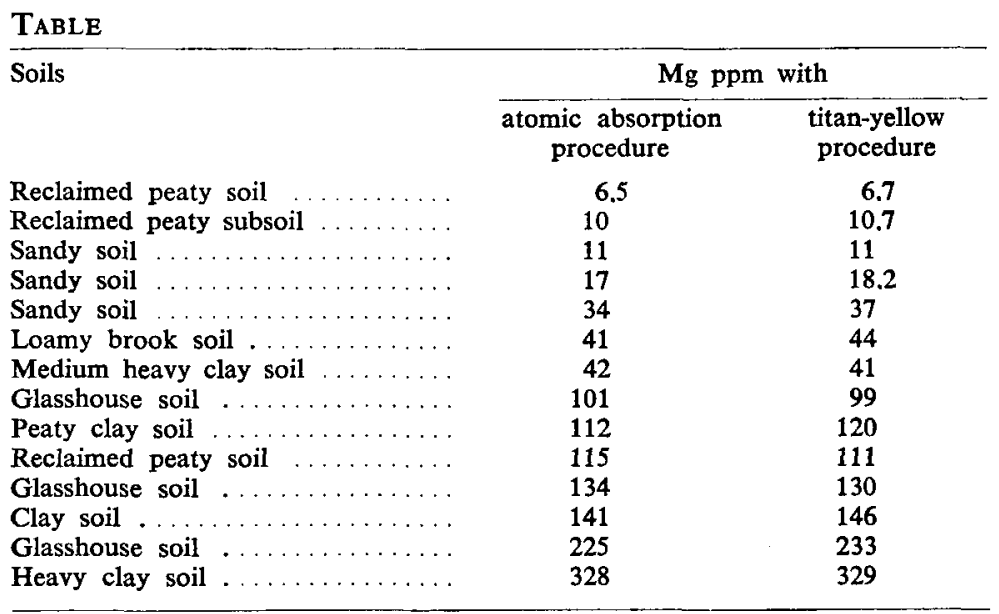

The agreement between the results is very satisfactory. 


\section{ACKNOWLEDGEMENT}

The author is indebted to Mr. I. WALINGA for the analytical work required for developing and testing the new method, and to Mr. A. D. VAN DER WEIJ for carrying out the atomic absorption analyses.

\section{Bradfield, E. G.}

LINDNER, R. C., and C. P. Harley

LINDNER, R. C.

LUNT, H. A., C. L. W. SWANSON, and

H. G. M. JACOBSON

SCHAUMLÖFFEL, E.

SChUfFElen, A. C., A. Muller and J. CH. VAN SCHOUWENBURG

Wesemael, J. Ch. Van

\section{REFERENCES}

1961 A rapid method for determining magnesium in plant material. The Analyst. 86, 269.

1962 A study of some factors which affect the adsorption of titan yellow on magnesium hydroxide. Anal. Chim. Acta. 27, 262.

1942 A rapid method for the determination of nitrogen in plant tissues. Science. 96, 565.

1944 Rapid analytical methods for some of the more common inorganic constituents of plant tissues. Pl. Physiol. 19, 76.

1950 The Morgan Soil Testing System. Conn. Agr. Expt. Sta. Bull. No. 541.

1960 Uber die colorimetrische Bestimmung der Mikronährstoffe Kupfer, Zink, Kobalt, Mangan, Eisen und Molybđän aus einer Aschenlösung durch fraktionierte Extraktion. Landw. Forsch. 13, 278.

1961 Quick tests for soil and plant analysis used by small laboratories. Neth. J. agric. Sci. 9, 1: 2-16.

1961 The determination of magnesium with titan yellow. Anal. Chim. Acta. 25, 238. 